\title{
Disease resistance induction in second-season corn using acibenzolar-S-methyl and phosphorylated mannanoligosaccharide
}

\section{Indução de resistência a doenças em milho de segunda safra por acibenzolar-S-metil e mananoligossacarídeo fosforilado}

\author{
Darci da Fontoura ${ }^{1 *}$; Antonio Carlos Torres da Costa ${ }^{2}$; \\ José Renato Stangarlin ${ }^{2}$; Claudio Yuji Tsutsumi ${ }^{2}$
}

\begin{abstract}
Resistance induction is an alternative method to reduce pesticide use in plant disease control. We conducted experiments with four corn hybrids over two consecutive years (2011 and 2012) in order to test resistance in second-season corn treated with acibenzolar-S-methyl (ASM) or phosphorylated mannanoligosaccharide (MOS). In addition, the plants were subjected to a fungicide (azoxystrobin + cyproconazole) or a control treatment using water only. Distinct pathogens were found in the harvests from both years, but the MOS treatment resulted in hypersensitive response during both years. None of the products applied affected plant height, ear insertion height, or damaged kernel percentage. MOS resulted in higher hypersensitive response intensity, without reducing productivity, compared to the water treatment. The application of ASM did not induce a hypersensitive response.
\end{abstract}

Key words: Agro-mos, bion, Exserohilum turcicum, fungicide, Puccinia polysora, Zea mays

\section{Resumo}

A indução de resistência se apresenta como um método alternativo para reduzir o uso de agrotóxicos no controle de doenças de plantas. Com o objetivo de verificar a indução de resistência na segunda safra de milho pelos indutores acibenzolar-S-metil (ASM) e mananoligossacarídeo fosforilado (MOS), experimentos foram conduzidos com quatro híbridos de milho em dois anos consecutivos (2011 e 2012). Além dos indutores de resistência, um fungicida (azoxistrobina + ciproconazole) foi aplicado, bem como pulverização com água como tratamento adicional. Foi observada incidência de patógenos distintos nos dois anos, embora o tratamento com MOS tenha resultado em resposta de hipersensibilidade em ambos os anos. Nenhum dos produtos aplicados afetou a altura de planta, altura de inserção da espiga e porcentagem de grãos ardidos. MOS aumenta a intensidade da resposta de hipersensibilidade, sem redução da produtividade em relação ao tratamento com água. A aplicação de ASM não induz resposta de hipersensibilidade.

Palavras-chave: Agromos, bion, Exserohilum turcicum, fungicida, Puccinia polysora, Zea mays

1 Biólogo, Dr., Pesquisador na DuPont do Brasil, Toledo, PR, Brasil. E-mail: darcifontoura@uol.com.br

2 Eng ${ }^{o s}$ Agros, Profs. Drs., Centro de Ciências Agrárias, Universidade Estadual do Oeste do Paraná, UNIOESTE, Campus de Marechal Cândido Rondon, PR, Brasil.E-mail: antonio.costa2@unioeste.br; jose.stangarlin@unioeste.br; cytsutsu@uol.com.br * Author for correspondence 
Corn (Zea mays L.) is widely grown in Brazil and is one of the most important crops in the country in terms of sown area and kernel production, only second by soybean. The Brazilian climate allows farmers to have two crop seasons annually, and most of them sow soybean or corn in the spring and a second crop after harvest, which occurs in January and February; the second crop is usually corn in succession after soybean. This second crop represents approximately half of the area farmed with corn in Brazil (CONAB, 2013).

This continuation of corn crops provides favorable conditions for pathogen survival, increasing the inoculum pressure for fungi that attack leaves, stem, and kernels, and consequently necessitating phytosanitary treatment. In this context, in addition to the application of fungicides, induction of resistance by activating the plants' latent structural and biochemical defense mechanisms is a viable alternative for controlling these phytopathogens (STANGARLIN et al., 2011).

In addition to the defense mechanisms, plants may have a hypersensitive response, in which a limited number of host cells surrounding the infection sites die in order to prevent pathogen development in their tissues (BOUBAKRI et al., 2012). This defense, the "suicide" of some cells to benefit others, is more efficient against biotrophic pathogens, as it restricts their access to water and nutrients. Morphologically, it is recognized as localized chlorosis that appears approximately 24 hours after infection and may develop into a necrotic lesion (GLAZEBROOK, 2005).

However, induced resistance results in energy expenditure and should therefore only be triggered with the actual recognition of a pathogen, so that plants "decide" where to allocate their resources to improve the defense mechanisms or to promote growth and development (KUHN; PASCHOLATI, 2010). Thus, induced resistance may represent a metabolic cost for the plant, which should only occur in the presence of the pathogen, thus allowing resource allocation for this purpose only when necessary (BOSTOCK, 2005). Plants that allocate their resources to defense in the absence of pathogens may incur costs reflected in productivity, since the metabolic changes that lead to resistance have an associated fitness cost, which may be higher than the benefit (IRITI; FAORO, 2003).

Our study aimed to evaluate resistance in second-season corn, or off-season corn, induced by acibenzolar-S-methyl and phosphorylated mannanoligosaccharide inducers.

The experiments were conducted in Toledo, Paraná, Brazil (2439'37" S, 5345'59" W, and altitude of $545 \mathrm{~m}$ ), during the second crop season of two consecutive years (2011 and 2012), in soil classified as eutrophic Red Latosol.

The experiment was a randomized block design in a triple factorial scheme $(4 \times 3 \times 3)$ and an additional treatment, with three replicates, where the following were tested: (A) hybrid at four levels, (B) product at three levels, and (C) dose at three levels. The additional treatment consisted of spraying water, representing a zero dose factor level.

Each experimental unit comprised four sowing rows, each $5.0 \mathrm{~m}$ long and spaced $0.76 \mathrm{~m}$ apart from each other; only the two central rows were evaluated, with one border row on each side of the plot used to minimize the border effect. Another 0.35 $\mathrm{m}$ from each end of the row was also discarded to minimize the drift effect of the treatment performed in the adjacent plots. Thus, each plot had a useful (effective) area of $5.32 \mathrm{~m}^{2}$, totaling 34 plants $\left(65,000\right.$ plants ha $\left.^{-1}\right)$.

Four single-cross hybrids $(30 \mathrm{~F} 90 \mathrm{H}, 30 \mathrm{~K} 64 \mathrm{H}$, $30 \mathrm{~K} 73 \mathrm{H}$, and $\mathrm{P} 4042 \mathrm{H}$ ) were evaluated, so that at least one hybrid was tolerant and another susceptible to the main leaf diseases, since there was no defined phytopathological standard for the second crop season of the western Paraná region and evaluation was performed at the onset of the natural pathogen infection. The flowering cycle was another criterion for choosing the hybrids, which needed to be 
similar so that all the hybrids remained at the same growth stage when applying the products and when performing the evaluations.

Two resistance inducers, phosphorylated mannanoligosaccharide (MOS) and acibenzolarS-methyl (ASM), and a broad-spectrum fungicide (azoxystrobin + cyproconazole) were applied to evaluate performance in an environment with reduced incidence of disease. The plants were also subjected to an additional water treatment to evaluate performance without the effects of the inducers and fungicide. As neither resistance inducer had a record and specific recommendation for the corn crop, three doses of each product were tested that represented proportions of $0.5,1.0$, and 1.5 times the mean dose recommended for other annual crops. The mean doses were as follows: 12.5 g a.i. ha-1 for ASM, $1500 \mathrm{~mL}$ a.i. ha ${ }^{-1}$ for MOS, and $60 \mathrm{~mL}$ azoxystrobin $+24 \mathrm{~mL}$ cyproconazole a.i. $\mathrm{ha}^{-1}$ for the fungicide. The products were applied at the $\mathrm{V}_{8}$ and $\mathrm{V}_{\mathrm{T}}$ stages, respectively, using a backpack sprayer, with an empty conical jet-spraying nozzle and a spray volume proportional to $250 \mathrm{~L} \mathrm{ha}^{-1}$. Except for the difference in the application of the products under study, all other culture practices were the same in all the plots.

Sowing was performed on January 25, 2011 and January 24, 2012 in a no-tillage system on soybean straw (Glycine max).

Base fertilizer comprised $36 \mathrm{~kg}$ of nitrogen $(\mathrm{N})$, $90 \mathrm{~kg}$ of phosphorus $\left(\mathrm{P}_{2} \mathrm{O}_{5}\right)$, and $90 \mathrm{~kg}$ of potassium $\left(\mathrm{K}_{2} \mathrm{O}\right)$ per hectare, i.e., $450 \mathrm{~kg} \mathrm{ha}^{-1}$ of the 8-2020 formula (NPK). The topdressing was applied with urea, in two applications, the first at $\mathrm{V}_{3}$ with $54 \mathrm{~kg} \mathrm{ha}^{-1}$ of $\mathrm{N}$ and the second at $\mathrm{V}_{6}$ with $81 \mathrm{~kg}$ $\mathrm{ha}^{-1}$ of N. For insect control, granular carbofuran insecticide was applied at $1 \mathrm{~kg}$ a.i. ha ${ }^{-1}$ incorporated into the planting row, and within the first 45 days, methomyl, novaluron, spinosad, and thiamethoxam were applied to the shoots at $129 \mathrm{~g}$ a.i. ha ${ }^{-1}, 15 \mathrm{~g}$ a.i. ha $^{-1}, 48 \mathrm{~g}$ a.i. ha ${ }^{-1}$, and $35.2 \mathrm{~g}$ a.i. ha ${ }^{-1}$, respectively. For weed control, nicosulfuron selective herbicide was applied at $50 \mathrm{~g}$ a.i. ha ${ }^{-1}$.
Water was supplied for irrigation using a mobile lateral pivot to avoid water deficit. There was $200 \mathrm{~mm}$ of irrigation (eight $25-\mathrm{mm}$ applications) between the $\mathrm{V}_{12}$ and $\mathrm{R}_{2}$ growth stages during the second 2011 crop season. Despite the $969 \mathrm{~mm}$ of rainfall during the second 2012 crop season, the crops were supplemented with $100 \mathrm{~mm}$ water (four 25-mm applications) between the $\mathrm{V}_{4}$ and $\mathrm{V}_{\mathrm{T}}$ growth stages.

The following were evaluated in both experiments: hypersensitive response (characterized by the presence of 1-2 mm-wide small white dots), thousand-kernel weight (a thousand kernels counted in an electronic seed counter and weighed on a digital balance), and kernel yield (the ears harvested from the plots were threshed and then the weight and moisture content of the kernels were determined. Based on these data and the plot's useful area, kernel yield was calculated and recorded in $\mathrm{kg} \mathrm{ha}^{-1}$ with moisture content corrected to $15 \%$ ).

Turcicum leaf blight was evaluated in 2011 and polysora rust and damaged kernel percentage were evaluated in 2012. Damaged kernel percentage was determined in 250-g samples, where kernel rot without differentiated pathogens was evaluated; this evaluation comprised visual separation and determination of the percentage of kernels with altered color on more than a quarter of their surfaces.

The mean score given by three trained evaluators (who independently conducted their evaluations) was recorded to evaluate the diseases with a scoring scale, thus reducing the natural effect of subjectivity resulting from evaluation with a diagrammaticbased scoring scale. The percentage of the leaf area free of injury symptoms was converted to a score between 1 and 9, where score 1 ( 0 to $10 \%$ without injury) represented the lowest health, followed by score 2 (10-30\% without injury), score 3 (30-40\% without injury), score 4 (40-50\% without injury), score 5 (50-60\% without injury), score 6 (60-70\% without injury), score 7 (70-80\% without injury), score 8 (80-90\% without injury), and score 9 (90-100\% without injury), which represented the 
highest leaf health, and consequently, the lowest injury severity.

Statistical analysis was performed individually and jointly (two years), where the data were subjected to analysis of variance and the means were subsequently compared using a Tukey's test or regression analysis to test the relationship between the two variables, depending on the nature of the data, using the SAS computational program.

The rainfall index was significantly different between the two years during the growing season, especially after flowering in April, May, and June; this trimester was extremely dry in 2011 with only $143 \mathrm{~mm}$ of rain, while it was very rainy in 2012 with $893 \mathrm{~mm}$ of rain.

There were incidences of different pathogens in the same hybrids in the two consecutive years, despite sowing at the same site and remaining under the same management conditions. This observation corroborates the report by Resende et al. (2003), who found that there is no standardization in phytopathological behavior during the second crop season, most likely because of the effects of the varying climatic conditions over the years during the crop development period. During the second 2011 crop season, there was turcicum leaf blight but no damaged kernels were detected, whereas during the second 2012 crop season, there was polysora rust and a large percentage of damaged kernels.

Turcicum leaf blight only manifested during the 2011 experiment. The $30 \mathrm{~F} 90 \mathrm{H}$ hybrid proved to be the most susceptible, whereas the $30 \mathrm{~K} 73 \mathrm{H}$ hybrid was the most tolerant to this disease, regardless of the treatment. Among the products, the results obtained after treatment with the inducers (MOS and ASM) did not differ statistically from the control (water); thus, these inducers presented a lower efficacy than the fungicide. The fungicide dose in this study had a good correlation with the turcicum leaf blight score, where the half-dose resulted in significant pathogen control, as shown in Figure 1a. Similarly, Costa and Cota (2009) reported that fungicide treatment controlled most fungal diseases, including turcicum leaf blight.

Figure 1. (a) Relationship between fungicide dose (azoxystrobin + cyproconazole) and turcicum leaf blight score in four hybrids during the second 2011 crop season, where score 1 represents the highest severity and score 9 represents the lowest severity. (b) Relationship between phosphorylated mannanoligosaccharide (MOS) dose and hypersensitive response score in four hybrids during the 2011 and 2012 second crop seasons, where score 1 represents the highest intensity and score 9 represents the lowest intensity. Toledo, Paraná, Brazil.

(a)

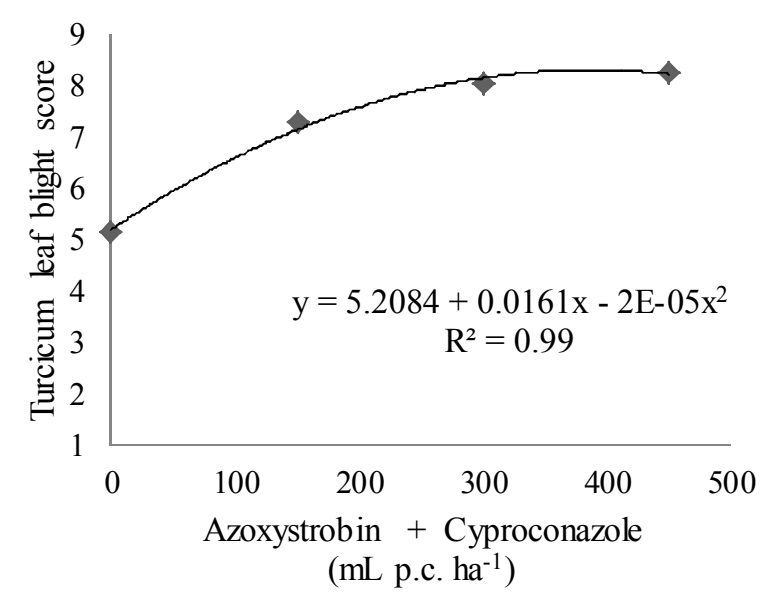

(b)

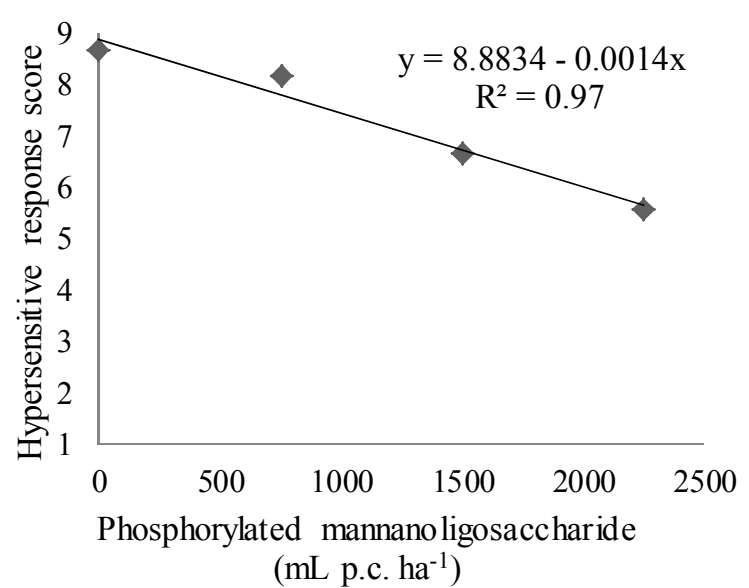


Hypersensitive responses occurred in both years, enabling joint analysis of both experiments. There were no significant differences between the water, ASM, and fungicide treatments, while MOS resulted in significantly higher hypersensitive response intensity in both years, with a higher intensity in 2012 than in 2011 (Table 1). Joint regression analysis (Figure 1b) showed that there was a significant positive correlation between MOS dose and hypersensitive response intensity. In a study testing the effect of $S$. cerevisiae on peroxidase activity in corn and sorghum, Roncatto and Pascholati (1998) found that the changes that occurred with peroxidase reflect recognition of the yeast cells or metabolites by a portion of the plants, leading to a change in their normal metabolism. In contrast, Gouvea (2007) evaluated the number of lesions caused by Mycosphaerella fragariae in strawberry plant leaves and found no difference between the treatments with $S$. cerevisiae, indicating that these treatments do not promote the formation of compounds that could restrict lesion growth.

Table 1. Hypersensitive response score, where score 1 represents the highest intensity and score 9 represents the lowest intensity, and kernel yield $\left(\mathrm{kg} \mathrm{ha}^{-1}\right)$ of four corn hybrids with phosphorylated mannanoligosaccharide (MOS), acibenzolar-S-methyl (ASM), fungicide (azoxystrobin + cyproconazole), and water applications during the 2011 and 2012 second crop seasons. Toledo, Paraná, Brazil.

\begin{tabular}{|c|c|c|c|c|}
\hline \multirow{2}{*}{ Product } & \multicolumn{2}{|c|}{ Hypersensitivity (score) } & \multicolumn{2}{|c|}{ Yield $\left(\mathrm{kg} \mathrm{ha}^{-1}\right)$} \\
\hline & 2011 & 2012 & 2011 & 2012 \\
\hline MOS & $6.85 \mathrm{Ab}$ & $5.08 \mathrm{Bb}$ & $7,626.75 \mathrm{Ab}$ & $7,559.16 \mathrm{Ab}$ \\
\hline ASM & $9.00 \mathrm{Aa}$ & $9.00 \mathrm{Aa}$ & $8,099.66 \mathrm{Ab}$ & 7,869.47 Ab \\
\hline Fungicide & $9.00 \mathrm{Aa}$ & $8.92 \mathrm{Aa}$ & $9,377.16 \mathrm{Aa}$ & $8,317.65 \mathrm{Ba}$ \\
\hline Water & $8.67 \mathrm{Aa}$ & $9.00 \mathrm{Aa}$ & $8,112.08 \mathrm{Ab}$ & $7,321.31 \mathrm{Ab}$ \\
\hline Overall mean: & \multicolumn{2}{|c|}{7.97} & \multicolumn{2}{|c|}{$8,141.64$} \\
\hline CV (\%): & \multicolumn{2}{|c|}{8.6669} & \multicolumn{2}{|c|}{11.8020} \\
\hline
\end{tabular}

* The same uppercase letters in rows and same lowercase letters in columns do not differ among themselves by the Tukey's test $(\mathrm{P} \leq 0.05)$.

Polysora rust was only sufficiently severe for evaluation in 2012. The $30 \mathrm{~K} 64 \mathrm{H}$ hybrid was more susceptible to polysora rust (lower score) in the resistance inducer and water treatments. However, when treated with fungicide, the $30 \mathrm{~K} 64 \mathrm{H}$ hybrid was not significantly different from the other hybrids, indicating that azoxystrobin + cyproconazole promoted good disease control, regardless of the dose used, as there was no interaction between product and dose. This report corroborates Costa and Cota (2009), who used this fungicide in controlling polysora rust. The $\mathrm{P} 4042 \mathrm{H}$ hybrid did not have significant differences among the treatments, as it has genetic resistance to this pathogen. The $30 \mathrm{~F} 90 \mathrm{H}$ and $30 \mathrm{~K} 73 \mathrm{H}$ hybrids, which have intermediate tolerance, only differed in that the fungicide treatment was the most effective, and similarly the $30 \mathrm{~K} 64 \mathrm{H}$ hybrid, classified as susceptible, had similar behavior in the water, MOS, and ASM treatments. The treatment with inducers (ASM and MOS) did not differ from the water treatment, indicating that they did not control polysora rust. Schipanski (2011) also reported that a fungicide treatment had better rust control, in this case caused by Puccinia sorghi, than an ASM treatment. In contrast, Costa et al. (2012) found no significant difference among fungicide treatments in controlling polysora rust.

The $30 \mathrm{~K} 64 \mathrm{H}$ and $\mathrm{P} 4042 \mathrm{H}$ hybrids had the worst kernel quality, whereas the $30 \mathrm{~K} 73 \mathrm{H}$ hybrid had the lowest damaged kernel percentage that did not significantly differ between the MOS, ASM, 
fungicide, and water applications. In evaluating the chemical control of Fusarium moniliforme, one of the causes of damaged kernels, Moraes et al. (2003) found that ASM did not control fungal development, showing higher fungal growth than the control at ASM concentrations of 10 and $1 \mu \mathrm{g} \mathrm{mL}{ }^{-1}$. This may be because ASM acts as a plant resistance inducer without acting on the pathogen. Small et al. (2012) reported that treatment with resistance inducers and a fungicide did not reduce Fusarium verticilioides intensity, another cause of damaged kernels, but there was a difference between the genotypes and environments. The thousand-kernel weight significantly differed among the hybrids in 2012; the P4042H hybrid had a higher thousandkernel weight, most likely due to its genetic traits, accompanied by the $30 \mathrm{~F} 90 \mathrm{H}$ hybrid, except in the ASM treatment. During the second crop season, Gonçalves et al. (2012) reported that the highest thousand-kernel weight was obtained using the fungicide.

When the years were analyzed individually, there were significant differences in kernel yield among hybrids and among products. The $30 \mathrm{~K} 64 \mathrm{H}$ hybrid had lower kernel yield during both years, regardless of treatment. The fungicide treatment increased kernel yield in both experiments, whereas the other treatments (water, ASM, and MOS) did not differ among themselves, having a lower yield (Table 1). This behavior differs from that reported by Costa and Cota (2009), who found that a susceptible cultivar had a higher increase in productivity than a resistant cultivar when compared to a control treatment. This most likely occurred because the gradient between susceptibility and resistance was higher during their experiment, as they tested hybrids from different gene banks from different companies. Similarly, Gonçalves et al. (2012) reported increased productivity with fungicide application.

The MOS resistance inducer increased the hypersensitive response intensity without reducing productivity compared to the water treatment, and ASM application did not induce a hypersensitive response (Table 1).

\section{Acknowledgements}

We thank the Agronomy graduate program at the Western Parana State University, Brazil, for stimulating the research, and DuPont of Brazil for supporting the experiments.

\section{References}

BOSTOCK, R. M. Signal crosstalk and induced resistance: straddling the line between cost and benefit. Annual Review of Phytopathology, Palo Alto, v. 43, p. 545-580, 2005.

BOUBAKRI, H.; WAHAB, M. A.; CHONG, J.; BERTSCH, C.; MLIKI, A.; SOUSTREGACOUGNOLLE, I. Thiamine induced resistance to Plasmopara viticola in grapevine and elicited hostdefense responses, including HR like-cell death. Plant Physiology and Biochemistry, Amsterdam, v. 57, p. 120133, 2012.

COMPANHIA NACIONAL DE ABASTECIMENTO - CONAB. Séries históricas relativas às safras 1976/77 a 2012/2013 de área plantada, produtividade e produção. Brasília, 2013. Disponível em: <http://www. conab.gov.br/conteudos.php? $\mathrm{a}=1252 \& \mathrm{t}=2 \&$ Pagina objcmsconteudos $=2 \#$ A_objcmsconteudos $>$. Acesso em: 21 mar. 2013.

COSTA, D. F.; VIEIRA, B. S.; LOPES, E. A.; MOREIRA, L. C. B. Aplicação de fungicidas no controle de doenças foliares na cultura do milho. Revista Brasileira de Milho e Sorgo, Sete Lagoas, v. 11, n. 1, p. 98-105, 2012.

COSTA, R. V.; COTA, L. V. Sistema integrado lavourapecuária: o modelo implantado na Embrapa milho e sorgo. Sete Lagoas: EMBRAPA, 2009. 11 p. (Circular técnica, 125).

GLAZEBROOK, J. Contrasting mechanisms of defense against biotrophic and necrotrophic pathogens. Annual Review of Phytopathology, Palo Alto, v. 43, p. 205-227, 2005.

GONÇALVES, M. E. M. P.; GONÇALVES JUNIOR, D.; SILVA, A. G.; CAMPOS, H. D.; SIMON, G. A.; SANTOS, C. J. L.; SOUSA, M. A. Viabilidade do controle químico de doenças foliares em híbridos de milho no plantio de safrinha. Nucleus, Ituverava, v. 9, n. 1, p. 49-62, 2012.

GOUVEA, A. Controle em campo e pós-colheita de doenças e metabolismo do morangueiro após tratamento com Saccharomyces cerevisiae. 2007. Tese (Doutorado em Agronomia) - Universidade Federal do Paraná, Curitiba. 
IRITI, M.; FAORO, F. Does benzothiadiazole-induced resistance increase fitness cost in bean? Journal of Plant Pathology, Bari, v. 85, n. 4, p. 265-270, 2003. Special Issue.

KUHN, O. J.; PASCHOLATI, S. F. Custo adaptativo da indução de resistência em feijoeiro mediada pela rizobactéria Bacillus cereus ou acibenzolar-S-metil: atividade de enzimas, síntese de fenóis e lignina e biomassa. Summa Phytopathologica, Botucatu, v. 36, n. 2, p. 107-114, 2010.

MORAES, M. H. D.; MENTEN, J. O. M.; GRAVENA, J. C.; ALVES, C. A. Controle químico de Fusarium moniliforme em sementes de milho: metodologia de avaliação e efeitos sobre a qualidade fisiológica. Fitopatologia Brasileira, Brasília, v. 28, n. 6, p. 626-632, 2003.

RESENDE, S. G.; PINHO, R. G.; VASCONCELOS, R. C. Influência do espaçamento entre linhas e da densidade de plantio no desempenho de cultivares de milho. Revista Brasileira de Milho e Sorgo, Sete Lagoas, v. 2, n. 3, p. 34-42, 2003.
RONCATTO, M. C.; PASCHOLATI, S. F. Alterações na atividade e no perfil eletroforético da peroxidase em folhas de milho (Zea mays) e sorgo (Sorghum bicolor) tratadas com levedura (Saccharomyces cerevisiae). Scientia Agricola, Piracicaba, v. 55, n. 3, p. 395-402, 1998.

SCHIPANSKI, C. A. Tratamento de sementes de milho com fungicidas e indutor de resistência e pulverização foliar para o controle da ferrugem comum do milho (Puccinia sorghi Schw). 2011. Dissertação (Mestrado em Agronomia) - Universidade Estadual de Ponta Grossa, Ponta Grossa.

SMALL, I. M.; FLETT, B. C.; MARASAS, W. F. O.; MCLEOD, A.; VILJOEN, A. Use of resistance elicitors to reduce fusarium ear rot and fumonisin accumulation in maize. Crop Protection, Amsterdam, v. 41, p. 10-16, 2012.

STANGARLIN, J. R.; KUHN, O. J.; TOLEDO, M. V.; PORTZ, R. L.; SCHWAN-ESTRADA, K. R. F.; PASCHOLATI, S. F. A defesa vegetal contra fitopatógenos. Scientia Agraria Paranaensis, Marechal Cândido Rondon, v. 10, n. 1, p. 18-46, 2011. 
